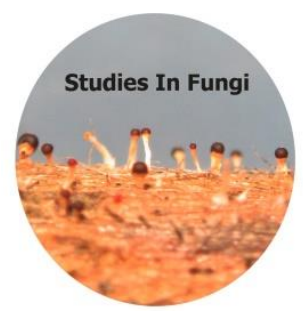

Studies in Fungi 2(1): 130-137 (2017) www.studiesinfungi.org ISSN 2465-4973

Article

Doi 10.5943/sif/ 2/1/15

Copyright $\odot$ Mushroom Research Foundation

\title{
Diversity of non-Laboulbenialean fungi on millipedes
}

\section{Enghoff $H$ and Reboleira ASPS}

Natural History Museum of Denmark, University of Copenhagen, Universitetsparken 15, DK-2100 Copenhagen OE, Denmark

Enghoff H, Reboleira ASPS 2017 - Diversity of non-Laboulbenialean fungi on millipedes. Studies in Fungi 2(1),130 -137, Doi 10.5943/sif/2/1/15

\begin{abstract}
New records are given for secondary capilliconidia of Basidiobolus from several species of millipedes (Diplopoda) belonging to three different orders. The anamorph 'Thaxteriola' stage of Rhynchomyces is recorded (with doubt) from a Brazilian millipede belonging to the order Spirostreptida. An enigmatic fungus showing characteristics of Coreomycetopsis, Hormiscioideus and Antennopsis is recorded from two species of Danish millipedes of the order Julida. Peculiar structures, tentatively referred to fungi are recorded from several millipede orders where they occur between micro-scutes of the external cuticle.
\end{abstract}

Key words - Amphoromorpha - Antennopsis - Ascomycota - Basidiobolus - Coreomycetopsis Diplopoda - Hormiscioideus - Mucoromycotina - Pyxidiophora - Rhynchomyces Zygomycota

\section{Introduction}

Millipedes (class Diplopoda) are well known as host of Trichomycetes (Lichtward 1986, Moss \& Taylor 1996), but several other kinds of fungi grow on the external cuticle of millipedes. Best known of these are Laboulbeniales, and over the last years, the diversity of Laboulbeniales on millipedes has increased significantly (Rossi \& Balazuc 1977, Santamaria et al. 2014, 2016, Enghoff \& Santamaria 2015). However, several types of small fungi which have nothing to do with Laboulbeniales are quite often found growing on the external cuticle of millipedes. We here present a review of the diversity of these non-laboulbenialean fungi on millipedes. Some of these can be referred to the 'Amphoromorpha' stage of the genus Basidiobolus Eidam, a genus currently classified in Zygomycota, Mucoromycotina, family Basidiobolaceae (MycoBank, www.mycobank.org, accessed 6 October 2017). The genus Amphoromorpha was described by Thaxter (1914) for minute amphora-shaped fungi found on earwigs and staphylinid beetles from the Philippine Islands. The systematic position of Amphoromorpha remained uncertain until Blackwell \& Malloch (1989) demonstrated similarity of Amphoromorpha with secondary capilliconidia of Basidiobolus. Amphoromorpha is accordingly regarded as a junior synonym of Basidiobolus, but because the name Amphoromorpha so well describes the shape of these fungi in the present paper we will use 'amphoromorph' as a short, 'trivial' name for the secondary capilliconidia of Basidiobolus. The first record of amphoromorphs from millipedes is due to Rossi \& Balazuc (1977) who reported on an Italian millipede, Ophyiulus targionii Silvestri, 1898 (order Julida, family Julidae) which was hosting a species of Laboulbeniales as well as an amphoromorph. 
Subsequently, amphoromorphs have been recorded from the Spanish Iberoiulus cavernicola Ceuca, 1967 (order Julida, family Blaniulidae) (Enghoff \& Reboleira 2014, Enghoff \& Santamaria 2015).

The genus Thaxteriola was described by Spegazzini (1918) for two species of tiny fungi found on earwigs (Dermaptera) and beetles (Coleoptera) in Argentina. A further three species of Thaxteriola were described by subsequent authors but Blackwell et al. (1986) presented evidence that Thaxteriola is nothing but an anamorph stage of the genus Pyxidiophora Bref. \& Tavel, a genus which itself is now regarded a synonym of Rhynchomyces Sacc. \& Marchal ex Marchal. (Ascomycota, www.mycobank.org, accessed 6 October 2017).

In addition to 'Amphoromorpha' and 'Thaxteriola' quite a number of small, simple fungi have been found on various arthropods. Thaxter (1920) coined the term 'Thaxteriolae' for this assemblage, most of which remains very poorly known. It would be futile to try to associate the fungi described below from Danish julids with any of the named genera of 'Thaxteriolae' and describing still another genus on the basis of our material would be irresponsible. We therefore simply present the fungi, hoping that eventually somebody will work out what they are. For the same reason, we also present images of some structures discovered during scanning electron microscopical studies of millipede cuticle which we cannot even refer to the kingdom of fungi with certainty.

\section{Materials \& Methods}

Millipedes stored in $70 \%$ ethanol in the zoological collection of the Natural History Museum of Denmark (ZMUC) were screened for fungal infestation.

One thallus from an Australian paradoxosomatid millipede was detached and mounted in Hoyer's medium with lactophenol on a slide (C-F-95160), while legs of Xestoiulus laeticollis (Porat, 1889) (Julidae) were temporary mounted in glycerine. Images and measurements of the fungus in the slides were made using an Olympus BX51 microscope with Differential Interference Contrast (DIC).

Specimens for Scanning Electron Microscopic (SEM) study were dried with a series of alcohol and acetone, coated with platinum/palladium and studied under with a JEOL JSM-6335F SEM. Backgrounds of the images were cleared using Adobe Photoshop software.

\section{Results}

\section{Amphoromorphs on millipedes}

We have found amphoromorphs on several millipedes, including Boreviulisoma barrocalense Reboleira \& Enghoff 2013 (order Polydesmida, family Paradoxosomatidae) (Fig. 1A), Acipes andalusius Enghoff \& Mauriès, 1999 (order Julida, family Blaniulidae) from Spain, an unidentified species of Spirostreptidae (order Spirostreptida) from Madagascar (Fig. 1B) and a further species of Paradoxosomatidae from Australia. The thallus of the latter (Fig. 1C) shows very close similarity with the holotype of Amphoromorpha entomophila Thaxter, illustrated by Blackwell \& Malloch (1989): from the darkened attachment disk a bottle-shaped thallus, $114 \times 41 \mu \mathrm{m}$, arises, terminating in a slender, $19 \times 7 \mu \mathrm{m}$ tubular extension. The attachment disk shows, by transparency, imprints of the cuticular scutes that each correspond to an underlying hypodermal cell (Fusco et al. 2000). The main body of the thallus, except for its basal $1 / 4$, is tightly packed with numerous cells ('segments' in the terminology of Blackwell \& Malloch, 1989). The tubular extension is open at the end, and it look as if a row of cells are on their way out of the terminal opening.

\section{'Thaxteriola' on a millipede}

Luiz Iniesta has kindly provided photographs of a fungus that has the typical size $(40 \times 10 \mu \mathrm{m})$ and shape of 'Thaxteriola' (Fig. 1D). It was found on the antenna of Pseudonannolene spelaea Iniesta \& Ferreira, 2013 (order Spirostreptida, family Pseudonannolenidae) from a Brazilian cave. Given the simplicity of the fungus and the limited evidence at hand, it is, however, far from certain that it is indeed a 'Thaxteriola'. 

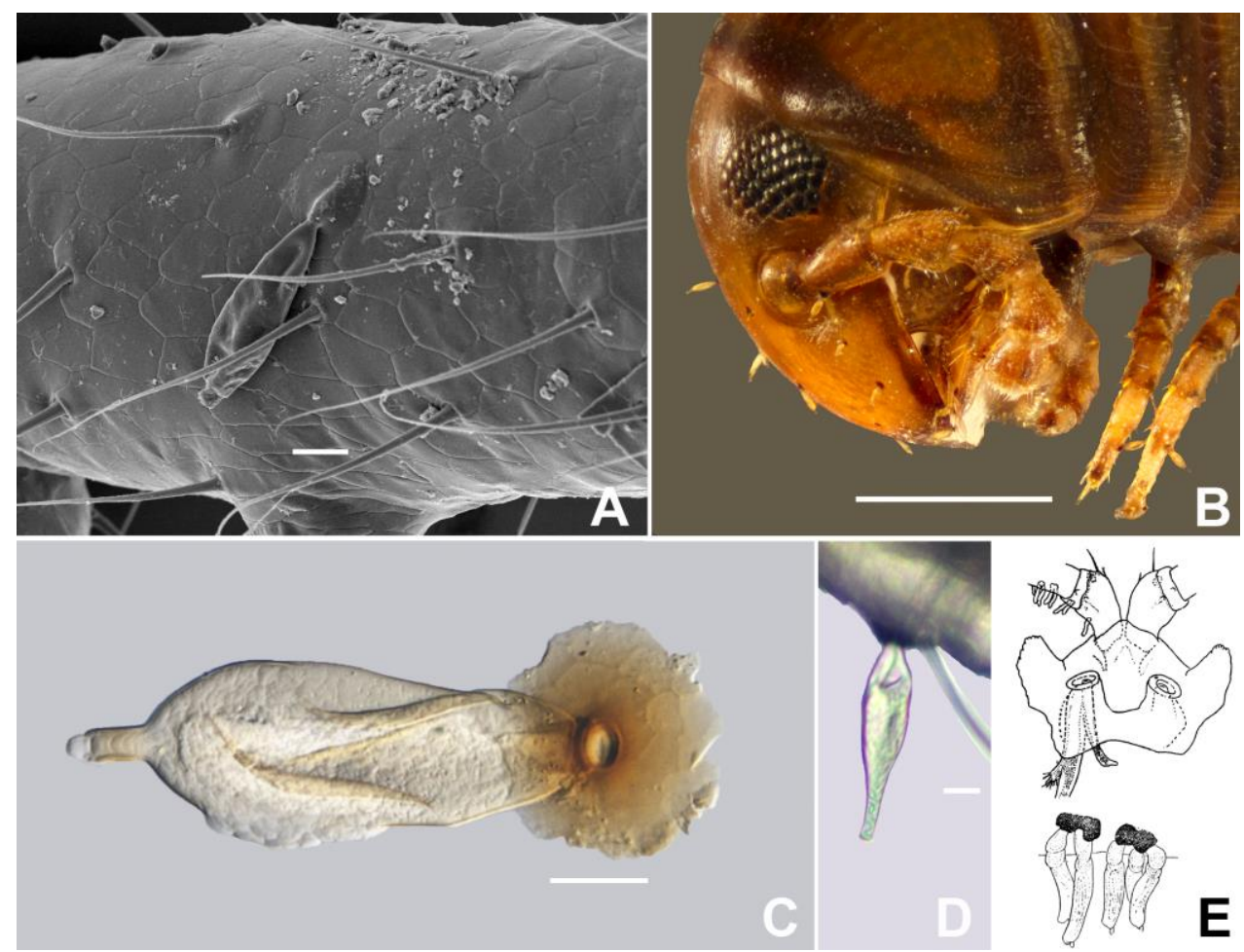

Fig. 1 - A Thallus of amphoromorph fungus on leg of Boreviulisoma barrocalense Reboleira \& Enghoff, 2013. B Unidentified species of Spirostreptidae from Madagascar (Montagne d'Ambre, $12^{\circ} 32^{\prime}$ S, 49¹0’E,NOV 1993, Coddington, Scharff, Larcher, Griswold \& Andriamasimanana leg.), with several thalli of amphoromorphs. C Thallus of amphoromorph from unidentified paradoxosomatid from Australia (NSW, Border Ranges NP, 22-23.iii.2010, N. Scharff \& G. Hormiga leg.). D Thallus of 'Thaxteriola' from Pseudonannolene spelaea Iniesta \& Ferreira, 2013 from a Brazilian cave. (Courtesy of L. Iniesta); B Fungi from Stemmiulus (Nethoiulus) sjoestedti (Brolemann, 1920) from Brolemann (1920). Scale bars: A, D = $10 \mu \mathrm{m}, \mathrm{B}=1 \mathrm{~mm}, \mathrm{C}=20 \mu \mathrm{m}$.

\section{Enigmatic fungi on millipedes}

Figs 2A-C, 3 show a fungus from the head and legs of several specimens of Xestoiulus laeticollis (Julidae) from Denmark. Each thallus is up to ca. $140 \mu \mathrm{m}$ long and consists of a darkened attachment cell plus a single row of up to a dozen rectangular cells of decreasing size. The attachment cell has a circular transparent "window", diameter ca. $2 \mu \mathrm{m}$, in its upper, less darkened part (Fig. 3B, F). On some thalli, cell number six or seven from the foot bears a small spinelike appendage (Fig. $3 \mathrm{E}$ ) and some thalli divide into ca. three branches after cell number 5 (Fig. 3A).

Fig. 2D-E shows a somewhat similar fungus, found on a juvenile of of another julid, Ophyiulus pilosus (Newport, 1842) from Denmark. Of this fungus we only found a few thalli, occurring in pairs or triplets on the millipede's legs. We only have SEM images; these show great similarty with SEM images of the fungus from Xestoiulus: a large attachment cell and a row of rectangular cells of decreasing size. We found no signs of a spinelike appendage or apical branching.

\section{Fungi at all?}

Akkari \& Enghoff (2011) first called attention to what they called "intercalary cuticular micro-scutes": rows of tiny (from less than 1 to a few $\mu \mathrm{m}$ diameter) circular to ovoid structures lying in neat rows between the cuticular micro-scutes of several species of millipedes. Using scanning electron microscopy Akkari \& Enghoff (2011) found these structures in several millipede families belonging to the order Polydesmida, but subsequently similar structures have been found in many species of the family Odontopygidae, order Spirostreptida) (Enghoff 2014, 2016) as well as one species of Cambalidae (order Spirostreptida) (Reboleira et al. 2015) and one species of 


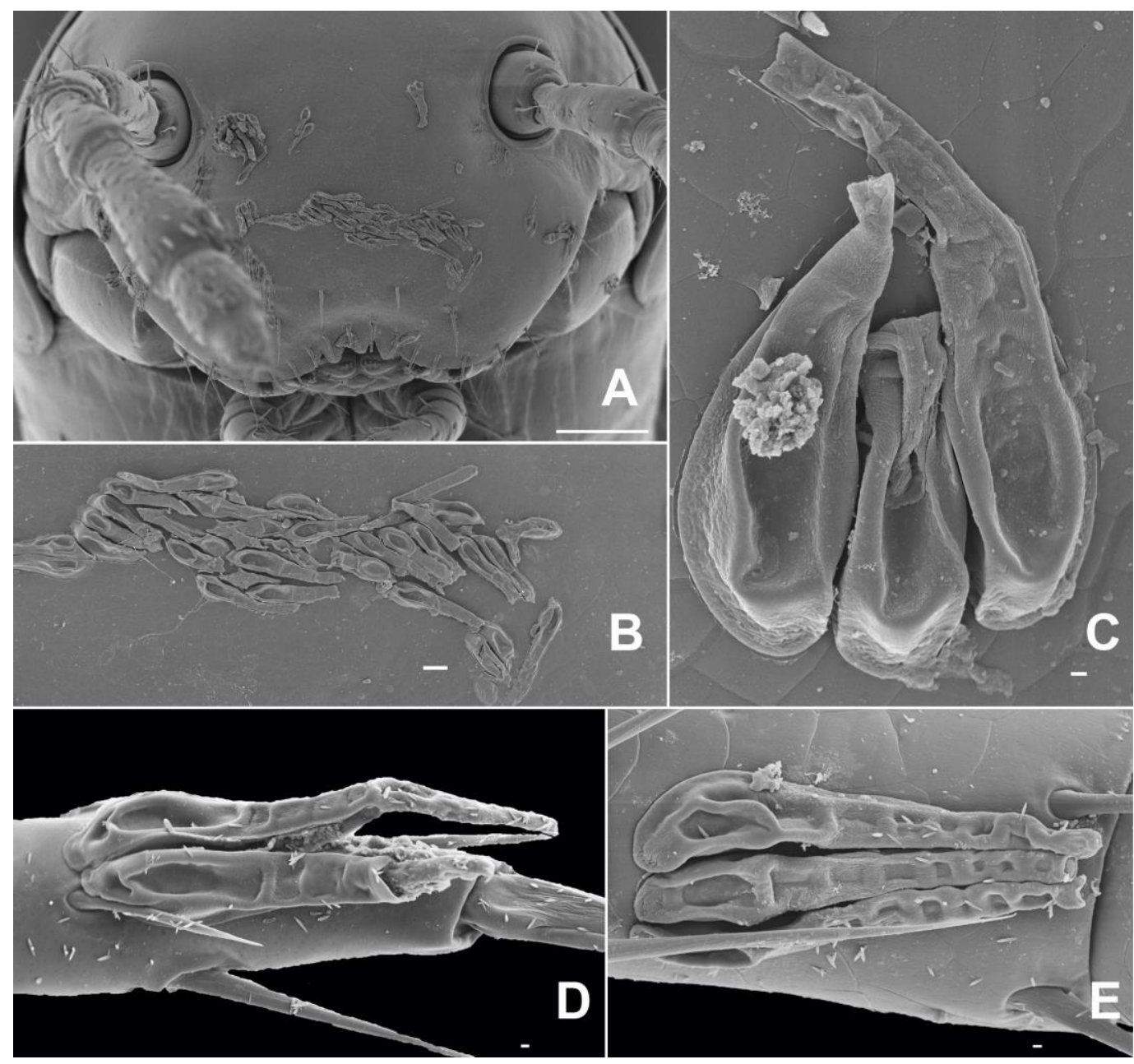

Fig. 2 - Scanning electron photographs of enigmatic fungi. A-C from Xestoiulus laeticollis (Porat,

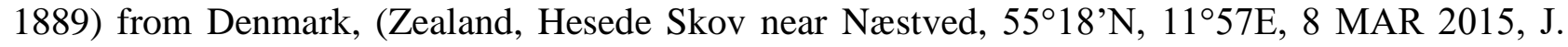
Pedersen leg.) and D-E) on Ophyiulus pilosus (Newport 1842) from Denmark (Lolland, Næsby Strand, 54 $45^{\prime} \mathrm{N}, 11^{\circ} 04 \mathrm{E}, 23$ FEB 2014, J. Pedersen leg.). A general view of the frontal view of the head of $X$. laeticollis with numerous thalli. B detail of a group of thalli. C thallus detail. D-E thalli on leg of Ophyiulus pilosus. Scale bars: $\mathrm{A}=100 \mu \mathrm{m}, \mathrm{B}=10 \mu \mathrm{m}, \mathrm{C}, \mathrm{D}, \mathrm{E}=1 \mu \mathrm{m}$.

Dorypetalidae (order Callipodida) (Reboleira \& Enghoff 2015). Fig. 4 shows a selection of these structures. They always occur along the borders between cuticular microscutes (each of which corresponds to an underlying hypodermis cell, cf. Fusco et al. 2000). Sometimes the circular-ovoid strutures are connected by a band (a hypha) and sometimes appear deflated (Fig. 4E) in a single case some were borne on short stalks (Fig. 4C-D) and one of the stalked micro-spheres appeared to have broken open (Fig. 4C, arrow).

So far, these structures are known only from scanning electron micrographs. Similar structures have, to our knowledge, not been reported from other arthropods, and it is a question whether they are at all of fungal nature. Toledo et al. (2010: Fig. 1C) showed a structure which they identified as a germ tube of Beauveria bassiana (Bals. -Criv.) Vuill. penetrating through a pore of the wax gland of a hemipteran insect - this structure looks quite like the one shown here on Fig. $4 \mathrm{C}-\mathrm{D}$. So far this is the only "match" we have been able to find and the fungal nature of the "intercalary cuticular micro-scutes" in millipedes remains unproven. 


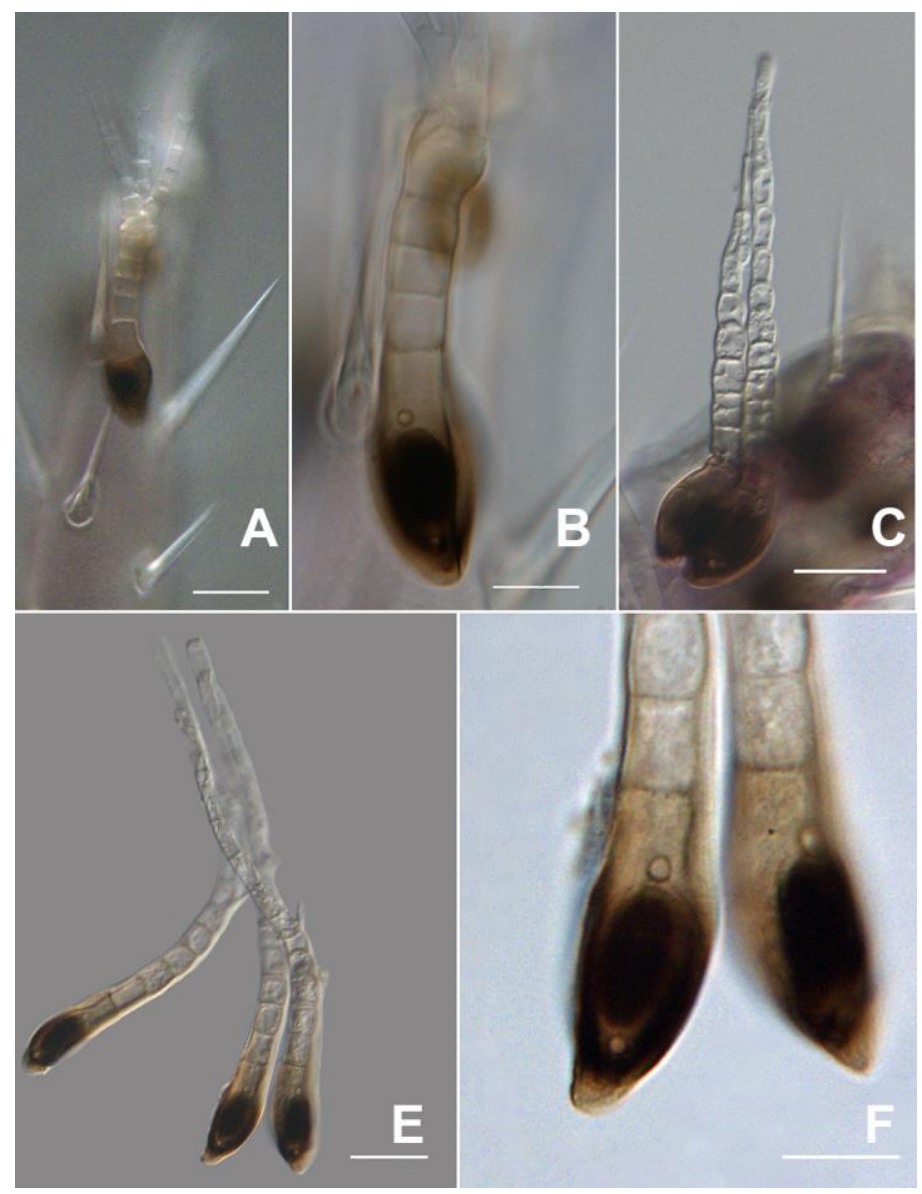

Fig. 3 - Enigmatic fungi from Xestoiulus laeticollis from Denmark (Zealand, Hesede Skov near

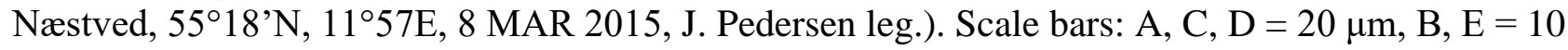
$\mu \mathrm{m}$.

\section{Discussion}

Our observations on amphoromorphs are in agreement with previous studies on Basidiobolus/Amphoromorpha. Dykstra \& Bradley-Kerr (1994) showed that the attachment disk is formed by an adhesive droplet. It seems that amphoromorphs do not invade the host cuticle: after removal of an amphoromorph fungus from a spider, the underlying cuticle showed no signs of penetration (Henriksen et al. 2017). In fact, an image of an amphoromorph on a millipede was presented by Reboleira \& Enghoff (2013: their fig. 8) in the description of Boreviulisoma barrocalense, however without pointing out the fungus. The enigmatic fungus from Xestoiulus laeticollis "seems to be most like a combination of Coreomycetopsis Thaxt. (for the attachment cell) and Hormiscioideus M. Blackw. \& Kimbr. or Antennopsis R. Heim. (for the filamentous part of the thallus). This is of course not really possible, so it could be new" (Meredith Blackwell in litt.). Coreomycetopsis, Hormiscioideus. and Antennopsis have all been described from termites (Blackwell \& Kimbrough 1976, 1978). The very small fungi described by Brolemann (1920) from Stemmiulus (Nethoiulus) sjoetedti (Brolemann 1920) (order Stemmiulida, family Stemmiulidae) from Tanzania (Fig. 1E) are equally enigmatic. Brolemann (1920) thought that they might be Laboulbeniales, but this is more than doubtful (cf. Rossi \& Balazuc 1977).

Surely, many more small fungi growing on millipede remain to be found. Our recent experience with Laboulbeniales (Santamaria et al. 2016) shows that close study of collections may reveal a high diversity of Laboulbeniales and most probably the non-laboulbenialean fungi are equally diverse. Unlike Laboulbeniales, which live on their host during their entire life cycle, amphoromorphs, 'Thaxteriola' etc. are stadia in more complicated life cycles involving different types of substrate and the isolated study of the phoretic stages can give only limited information. 

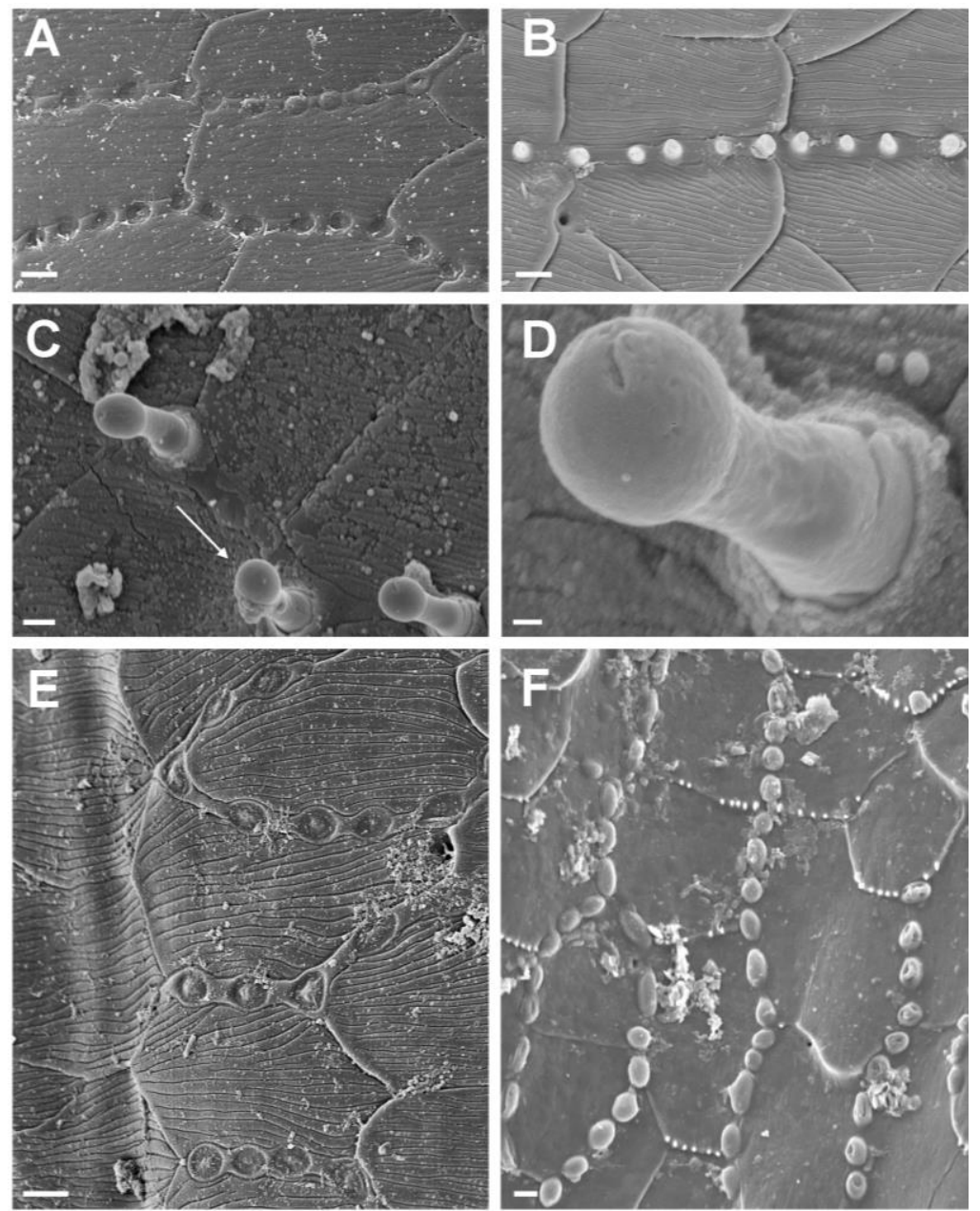

Fig. 4 - Fungi growing between cuticular microscutes of millipedes of the family Odontopygidae (order Spirostreptida, A-E and Dorypetalidae (order Callipodida, F). A from Chaleponcus netus Enghoff 2014. B from Prionopetalum kraepelini (Attems 1896). C-D from Chaleponcus nikolajscharffi Enghoff 2014, the arrow in Fig. 4C indicates an opened fungal body. E from $C$. tintin Enghoff 2014. F from Lusitanipus alternans (Verhoeff 1893). Scale bars: A, B, E, F = $2 \mu \mathrm{m}$; $\mathrm{C}=1 \mu \mathrm{m}, \mathrm{D}=0.2 \mu \mathrm{m}$. After Enghoff $(2014,2016)$ and Reboleira \& Enghoff (2015) modified.

These small organisms are likely to be overlooked, as some of the examples mentioned above show. As a curiosity it can be mentioned that not only diplopodologists and arachnologists overlook small fungi. In a recent paper Solodovnikov \& Shaw (2017) showed a SEM image of the tarsus of an Australian rove beetle (Coleoptera, family Staphylinidae). The beetle species in question is characterized by a peculiar comb which in Solodovnikov \& Shaw's image is indicated with a red bar. Incidentally the red bar ends at two long structures that look very much like the fungus described above from Danish julid millipedes. We have been able to re-examine the SEM mount and confirm the similarity of the fungus with those found on Xestoiulus and Ophyiulus.

\section{Acknowledgements}

We are grateful to Luiz Iniesta for kindly providing Fig. 1D to Jan Pedersen for the material of enigmatic fungi from Danish julids, to Alexey Solodovnikov and Josh Shaw for access to their SEM mount of an infected rove beetle, to Meredith Blackwell for her comments on these fungi and to Sergi Santamaria, Jørgen Eilenberg and Henrik de Fine Licht for general mycological advice. 


\section{References}

Akkari N, Enghoff H. 2011 - On some surface structures of potential taxonomic importance in families of the suborders Polydesmidea and Dalodesmidea (Polydesmida, Diplopoda). Zookeys 156, 1-4. http://dx.doi.org/10.3897/zookeys.156.2134

Blackwell M, Kimbrough JW. 1976 - A developmental study of the termite-associated fungus Coreomycetopsis oedipus. Mycologia 68(3), 551-58.

Blackwell M, Kimbrough JW. 1978 - Hormiscioideus filamentosus gen. et sp. nov., a termiteinfesting fungus from Brazil. Mycologia 70(6), 1274-1280.

Blackwell M, Bridges JR, Moser JC, Perry TJ. 1986 - Hyperphoretic dispersal of a Pyxidiophora anamorph. Science 232, 993-995.

Blackwell M, Malloch D. 1989 - Similarity of Amphoromorpha and secondary capilliconidia of Basidiobolus. Mycologia 81, 735-741.

Brolemann HW. 1920 - Diplopoda. In: Voyage de Ch. Alluaud et R. Jeannel en Afrique Orientale (1911-1912). Résultats scientifiques. Myriapoda, III, pp. 49-298 + pl V-XVIII.

Ceuca T. 1967. - Iberoiulus, un genre nouveau de myriapode (Diplopoda-Blaniulidae). Miscellania Zoologica 2 (2), 31-34.

Dykstra MJ, Bradley-Kerr B. 1994 - The adhesive droplet of capilliconidia of Basidiobolus ranarum exhibits unique ultrastructural features. Mycologia 86, 336-342.

Enghoff H. 2014 - A mountain of millipedes I: An endemic species-group of the genus Chaleponcus Attems, 1914 from the Udzungwa Mountains, Tanzania (Diplopoda, Spirostreptida, Odontopygidae). European Journal of Taxonomy 100, 1-75. http://dx.doi.org/10.5852/ejt.2014.100

Enghoff H. 2016 - A mountain of millipedes IV: Species of Prionopetalum Attems, 1909 from the Udzungwa mountains, Tanzania. With notes on "P." fasciatum (Attems 1896) and a revised species key (Diplopoda, Spirostreptida, Odontopygidae). European Journal of Taxonomy 215, 1-3. http://dx.doi.org/10.5852/ejt.2016.215.

Enghoff H, Mauriès JP. 1999. - The genus Acipes in Spain, with the description of a new cavernicolous species (Diplopoda, Julida, Blaniulidae). Entomologica scandinavica 30, 3133.

Enghoff H, Reboleira ASPS. 2014 - Redescription of Iberoiulus cavernicola Ceuca, 1967 and the relationships of the genus Iberoiulus Mauriès, 1985 (Diplopoda, Julida, Blaniulidae). Zootaxa 3869 (2), 153-158. http://dx.doi.org/10.11646/zootaxa.3869.2.4

Enghoff H, Santamaria S. 2015 - Infectious intimacy and contaminated caves - three new species of ectoparasitic fungi (Ascomycota: Laboulbeniales) from blaniulid millipedes (Diplopoda: Julida) and inferences about their transmittal mechanisms. Organisms Diversity \& Evolution 15(2), 249-63. http://dx.doi.org/10.1007/s13127-015-0208-8

Fusco G, Brena C, Minelli A. 2000 - Cellular processes in the growth of lithobiomorph centipedes (Chilopoda: Lithobiomorpha). A cuticular view. Zoologischer Anzeiger 239, 91-102.

Henriksen CB, Reboleira ASPS, Scharff N, Enghoff H. 2017 - First record of a Basidiobolus/Amphoromorpha fungus from a spider. African Journal of Ecology, online 12 June 2017. https://doi.org/10.1111/aje.12430

Iniesta LFM, Ferreira RL. 2913. - The first troglobitic Pseudonannolene from Brazilian iron ore caves (Spirostreptida: Pseudonannolenidae). Zootaxa 3669(1), 85-95.

Lichtward RW. 1986 - The Trichomycetes - fungal associates of arthropods. Springer.

Moss ST, Taylor J. 1996 - Mycobionts in the guts of millipedes - the Eccrinales. Mycologist 10(3), 121-24.

Newport G. 1842. - Description of a new British Iulus. Annals and Magazine of Natural History 11,316 .

Porat CO. 1889. - Nya bidrag til Skandinaviska Halföns myriopodologi. - Entomologisk Tidskrift $10,33-48+65-80+113-148$. 
Reboleira ASPS, Enghoff H. 2013 - The genus Boreviulisoma Brolemann, 1928 - an Iberian-N African outlier of a mainly tropical tribe of millipedes (Diplopoda: Polydesmida: Paradoxosomatidae). Zootaxa 3646, 516-528. http://dx.doi.org/10.11646/zootaxa.3646.5.2

Reboleira ASPS, Enghoff H. 2015 - Redescription of Lusitanipus alternans (Verhoeff 1893) (Diplopoda, Callipoda, Dorypetalidae) and ecological data on its Laboulbeniales ectoparasites in caves. - Zootaxa 3957, 567-576. http://dx.doi.org/10.11646/zootaxa.3957.5.5

Reboleira ASPS, Hosseini MJM, Sadeghi S, Enghoff H. 2015 - Highly disjunct and highly infected millipedes - a new cave-dwelling species of Chiraziulus (Diplopoda: Spirostreptida: Cambalidae) from Iran and notes on Laboulbeniales ectoparasites. European Journal of Taxonomy 146, 1-18. http://dx.doi.org/10.5852/ejt.2015.146

Rossi W, Balazuc J. 1977 - Laboulbéniales parasites de Myriapodes. Revue de Mycologie 41, 52535.

Santamaria S, Enghoff H, Reboleira ASPS. 2014 - Laboulbeniales on millipedes: the genera Diplopodomyces and Troglomyces. Mycologia 106(5), 1027-1038. http://dx.doi.org/10.3852/13-381

Santamaria S, Enghoff H, Reboleira ASPS. 2016 - Hidden biodiversity revealed by collections based research - Laboulbeniales in millipedes: genus Rickia. Phytotaxa 243(2), 101-127. http://dx.doi.org/10.11646/phytotaxa.243.2.1

Silvestri F. 1898. - Contribuzione all conoscenza dei Diplopodi della fauna Mediterranea. Annali del Museo civico di Storia naturale di Genova 38, 654-669, pl. 3-5.

Solodovnikov A, Shaw JJ. 2017 - The remarkable Australian rove beetle genus Myotyphlus: its cryptic diversity and significance for exploring mutualism among insects and mammals (Coleoptera: Staphylinidae). Austral Entomology 56, 311-321. http://dx.doi.org/10.1111/aen.12233

Spegazzini C. 1918 - Observaciones microbiológicas. Anales de la Sociedad Científica Argentina $85,311-323$.

Thaxter R. 1914 - On certain fungus-parasites of living insects. Botanical Gazette 58, 235-253.

Thaxter R. 1920 - Second note on certain peculiar fungus-parasites of living insects. Botanical Gazette 69(1), 1-27.

Toledo AV, De Remes Lenicov AMM, López Lastra C. 2010 - Histopathology caused by the entomopathogenic fungi, Beauveria bassiana and Metarhizium anisopliae, in the adult planthopper, Peregrinus maidis, a maize virus vector. Journal of Insect Science 10(1), 35. https://doi.org/10.1673/031.010.3501 